\title{
SWV determination of glyphosate in Burkina Faso soils using carbon fiber microelectrode
}

\author{
Issa TAPSOBA ${ }^{1 *}$, Samuel PARÉ ${ }^{1}$, Adama M. TOÉ ${ }^{2}$, Boukaré KABORÉ ${ }^{1}$, \\ Bazoumana KOULIBALY ${ }^{3}$ and Yvonne L. BONZI-COULIBALY ${ }^{1}$ \\ ${ }^{1}$ Laboratoire de Chimie Organique: Structure et Réactivité, UFR/SEA; Université de Ouagadougou, \\ 03 BP 7021 Ouagadougou 03 Burkina Faso. \\ ${ }^{2}$ Institut de Recherche en Sciences de la Santé (IRSS), Direction Régionale de l'Ouest, Bobo Dioulasso, BP \\ 545 Bobo Dioulasso, Burkina Faso. \\ ${ }^{3}$ Institut de L'Environnement et de Recherches Agricoles (INERA), Programme Coton, 01 BP 208 Bobo \\ Dioulasso, Burkina Faso. \\ *Corresponding author; Email: issa.tapsoba@univ-ouaga.bf; Phone: + 22670625536
}

\begin{abstract}
This paper presents an evaluation using carbon fiber microelectrode (CFME) for the determination of glyphosate in soils from Burkina Faso treated with Glyphonet SL 360 by square wave voltammetry (SWV). The maximum intensity of the electrochemical response signal of glyphosate has been optimized and conditions using a $0.2 \mathrm{M}$ of phosphate buffer solution at $\mathrm{pH} 5.2$ as supporting electrolyte and the SWV parameters frequency of $60 \mathrm{~Hz}$, a scan increment of $10 \mathrm{mV}$ and a pulse height of $60 \mathrm{mV}$. The limit of detection for glyphosate in the Glyphonet SL 360 formulation was $25 \mu \mathrm{g} \mathrm{L}^{-1}$ while the quantification limit was $83 \mu \mathrm{gL}^{-1}$ with a linear dynamic range up to $50 \mu \mathrm{g} \mathrm{L}^{-1}$. In these conditions, a sequence of experiments led to recoveries in the range 88.5 to $102.3 \%$ for soil samples spiked with 50,100 and $200 \mu \mathrm{gL}^{-1}$ of glyphosate with a standard deviation of $11.5,4.2$ and $2.3 \%$ respectively indicating the precision of the method. The optimized method was successfully applied to determine the residues of glyphosate in soils collected in the fields in two different dates from the application period.
\end{abstract}

(c) 2012 International Formulae Group. All rights reserved.

Keywords: Glyphosate, Glyphonet SL 360, carbon fiber microelectrode, square wave voltammetry, sensitivity.

\section{INTRODUCTION}

$\mathrm{N}$-(phosphonomethyl) glycine, aka Glyphosate, is a nonselective herbicide and the most commonly used agricultural pesticide (Franz et al., 1997). This herbicide sale represents about $60 \%$ of the worldwide market of herbicides, totaling 1.2 billion dollars per year, making this product the nonselective herbicide most extensively applied, mainly due to its broad spectrum for the elimination of weeds (Franz et al., 1997; Amarante et al., 2002).

The extensive use of this herbicide is worrying the environmentalists. Nevertheless, the environmental effects, as in the flora and thus in the microbiological soil population, are pernicious (Morrison et al., 1984; Bott et al., 2011; Haney et al., 2000). This situation is worsened due to its possible accumulation. Thus, Studies of the physicochemical 
properties of glyphosate, its interactions with water and soil components, as well as its extraction, detection and quantification in natural samples are necessary for a wellknown of this component due to its effects on environment (Amarante et al., 2002; Pintado et al., 2012).

At the present, most studies for the analysis of glyphosate and its principal degradation product, aminomethylphosphonic acid (AMPA), make use of derivatization steps (Ibanez et al., 2006) or complex eluent like in ion exchange chromatography (European Commission, 2002).

Studies showed that glyphosate skeleton presents a secondary amino group that, when treated with nitrous acid is converted to an N-nitro group (Marsh et al., 1992). This one can be easily reduced; making some authors (Bronstad et al., 1976; Friestad et al., 1985; Moraes et al.; 2010) showed the possibility of applying differential pulse polarography (DPP) as an inexpensive and fast technique for glyphosate determination.

In the present work, the main objective is to develop and validate an electrochemical method for the determination of glyphosate formulated in Glyphonet SL360 in soils from Burkina Faso using carbon fiber microelectrodes based on square wave voltammetry. The optimization of the SWV voltammetric response in the glyphosate determination was carried out and compared with liquid chromatography using diode array detector, for the determination of glyphosate's residues in soils collected at the north-west of Burkina Faso.

\section{MATERIALS AND METHODS Reagents}

Standard glyphosate (99.8\%), AMPA (98\%) and glyphonet 360 SL were received from DTE Datung Group. Acetic acid (99.8\%), acetonitrile $\left(\mathrm{CH}_{3} \mathrm{CN}\right) \quad(99.9 \%)$, sodium chloride $(\mathrm{NaCl})(99.5 \%)$, potassium dihydrogenophosphate $\left(\mathrm{KH}_{2} \mathrm{PO}_{4}\right) \quad(\mathrm{ACS}$ reagent, $98 \%)$, potassium hydrogenophosphate $\left(\mathrm{K}_{2} \mathrm{HPO}_{4}\right)$ (ACS reagent,
98\%) and potassium hydroxide $(\mathrm{KOH})$ (ACS reagent, 98\%) were purchased from Sigma Aldrich.

Apparatus
Cyclic voltammetry $(\mathrm{CV})$ and square
wave voltammetry measurements were wave voltammetry measurements were performed using an electrochemical analyzer PalmSens, (PalmSens Instrument, Netherlands) connected to a personal computer using Ivium PC and PSLite software. A three-electrode configuration was employed consisting of a carbon fiber microelectrode $(12 \mu \mathrm{m}$ diameter with a length of $5 \mathrm{~mm}$ ) purchased from WPI, USA. The carbon electrode surface was renewed by a homemade electrochemical treatment. Indeed, the carbon fiber microelectrodes were first pretreated electrochemically in a mixture of sulfuric acid (0.5M)/ethanol (50/50 w/w) followed by a treatment in $0.2 \mathrm{M}$ phosphate buffer solution using following conditions: potential scanning rate of $100 \mathrm{mVs}^{-1}$ in the potential range -1.0 to $1.5 \mathrm{~V}$ vs $\mathrm{Ag} / \mathrm{AgCl}(\mathrm{KCl}$ $0.1 \mathrm{M}$ ) during 20 cycles. The quality of these microelectrodes was controlled by checking out of the $\mathrm{Fe}(\mathrm{CN})_{6}{ }^{4-}$ electrochemical response as a probe. $\mathrm{An} \mathrm{Ag} / \mathrm{AgCl}(\mathrm{KCl} \quad 0.1 \mathrm{M})$ electrode was used as a reference and stainless wire as auxiliary electrode. Electrochemical experiments were carried out in a $10-\mathrm{mL}$ glass voltammetric cell at room temperature. In this, 20 sensitive CFME were elaborated after the quality control for a complete investigation.

The comparative study was realized at the National Laboratory of Public Health (LNSP) using reverse phase HPLC with a high sensitivity diode array detector, and Agilent Zorbax chromatographic column with the following reference: Zorbax Eclipse XDB C18 $4.6 \times 250 \mathrm{~mm}, 5 \mu \mathrm{m}$ of particles. The mobile phase was constituted of potassium dihydrogenophosphate/methanol at 96/4 ratio.

\section{Solution preparation}

A stock solution of glyphosate $\left(1\right.$ g. $\left.\mathrm{L}^{-1}\right)$ was prepared by dissolving the equivalent mass of glyphosate in acetonitrile. $0.2 \mathrm{M}$ 
phosphate buffer solution was used as the supporting electrolyte. The $\mathrm{pH}$ of the phosphate buffer solution was measured by a $\mathrm{pH}$ combined electrode and the exact value of $\mathrm{pH}$ was adjusted by addition of aqueous potassium hydroxide.

\section{Experimental design and treatments}

Tests in cotton and maize fields were conducted according to a simple block design on an area of 0.75 ha. The formulated glyphosate, Glyphonet SL 360, is applied on 0.5 ha and the untreated control plot is 0.25 ha. Tests on upland rice are conducted on an area. In this case, the untreated control plot is 0.15 ha. Glyphonet SL 360 is applied to soil in grassed or direct seeding after tillage. The dose used was $1080 \mathrm{~g} \mathrm{ha}^{-1}$ of Glyphonet, this according to the importance of weed.

\section{Soil samples}

Because glyphosate is strongly adsorbed to the soil surface by particles (Borggaard et al., 2008; Nicholls et al., 1991), we limited the research of glyphosate residues at the depth of $20 \mathrm{~cm}$. According to a well established methodology for soils sampling (Reinaldo et al., 2008), 13 samples were taken in each field and mixed to form a composite sample. This composite sample was crushed and sieved through a sieve of 20 microns porosity according to a procedure described previously (Teofilo et al., 2008) and stored in the refrigerator at $-20^{\circ} \mathrm{c}$ until analysis. In each case, a witness sample was taken before the application of herbicides in order to perform a physicochemical characterization of the different soils and to determine the state and the initial content of the residues of glyphosate soil prior to up tests.

An amount of $50 \mathrm{~g}$ of the composite soil was added to $125 \mathrm{~mL}$ of a $0.2 \mathrm{M} \mathrm{KOH}$ solution in a flask that was then closed and mechanically stirred for $15 \mathrm{~min}$. All the volume was centrifuged during $15 \mathrm{~min}$ at $2000 \mathrm{rpm}$ and the supernatant was transferred to a plastic flask. This operation was duplicated.

\section{RESULTS AND DISCUSSION \\ Direct electrochemical detection of glyphosate}

Figure 1 illustrates a SWV typical electrochemical response of glyphosate in acetate buffer solution at pH 5 using carbon fiber microelectrode. Indeed, as it is shown in this figure, a well defined redox peak appeared at $-875 \mathrm{mV}$ versus $\mathrm{Ag} / \mathrm{AgCl} / \mathrm{KCl}$ $0.1 \mathrm{M}$ and assigned to the reduction of acid group of glyphosate. This result is in agreement with previously reported works (Teofilo et al., 2008).

Recent studies (Sbai et al., 2007; Pontié et al., 2010) have demonstrated that CFME modified with combination of phtalocyanine and Nafion could be used without preelectrolysis step for the detection of methylparathion with a sensitivity of $20 \mathrm{nA} \mathrm{L}$ $\mathrm{mg}^{-1}$ and a determination limit of $100 \mu \mathrm{g} \mathrm{L}^{-1}$ under optimized SWV parameters. We previously demonstrated the possibility of carbon fiber microelectrode use, modified or not by tetrasulfonated nickel phtalocyanine to follow parathion methyl and its stable byproducts such as p-nitrophenol (Tapsoba et al., 2009; 2012). In order to determine the most suitable conditions for glyphosate residues determination in soils based on carbon fiber microelectrode, we optimized the square wave voltammetry parameters.

\section{Improvement of the sensitivity of carbon fiber microelectrode for glyphosate analysis \\ The electrochemical behavior of glyphosate on CFME was optimized in phosphate buffer solutions, the $\mathrm{pH}$ ranging from 2 to 11 by square wave voltammetry for the highest current intensity. Moreover, the square wave voltammetry parameters such as the frequency, the pulse height and the scan increment were also investigated for an optimum response of glyphosate using carbon} fiber microelectrode.

Figure 2 shows the variation of the current intensity of the reduction peak of glyphosate with the $\mathrm{pH}$ value of the phosphate buffer solution. It is obvious through the 
figure that the $\mathrm{pH}$ of the supporting electrolyte has an great effect on the efficiency of the electrochemical detection of glyphosate as it is reported elsewhere (Izutsu 2002; US EPA, 2006; Nicholls et al., 1991; Shifu et al., 2007). As it is illustrated on Figure 2, one can conclude that the highest current intensity corresponding to glyphosate reduction on carbon fiber microelectrode is obtained for a $\mathrm{pH}$ close to 7.2 , suggesting that at this $\mathrm{pH}$ value, glyphosate is relatively stable and is probably on easily reducible form. These results are in good agreement with those reported in the literature indicating that glyphosate formulations are stables in water at $\mathrm{pH}$ 4-9 range at $35^{\circ} \mathrm{C}$ and stable for photodegradation in $\mathrm{pH} \mathrm{5,7}$ and 9 in buffered solutions under natural sunlight (Nicholls et al., 1991; Shifu et al., 2007). In addition, one could explain the low intensity at $\mathrm{pH}>10.2$, by a possible degradation of glyphosate that lowers its concentration in the buffer. At lower $\mathrm{pH}$, one can observe a very low current intensity relative to the reduction of glyphosate. This behavior can be explained by a degradation of the glyphosate at low $\mathrm{pH}$ values and these obtained results are in agreement with those reported by Shifu et al. (2007) and Aquino et al. (2009)

Taking account of this optimal value of $\mathrm{pH}$, we fixed the $\mathrm{pH}$ of the phosphate buffer solution at 5.2 while following the variation effects of the SWV parameters. The choice of this value is dictated by the soils acidity which is generally close to $\mathrm{pH} 5$.

Figure 3 presents the frequency influence upon the SWV response in terms of stripping peak current. The plotting shows that the reduction peak current reaches a maximum at $60 \mathrm{~Hz}$ frequency which was adopted for all the following experiments.

In the case of scan increment and the pulse height, the investigations show that the best current intensity is obtained for a pulse height of $60 \mathrm{mV}$ and a scan increment of 10 $\mathrm{mV}$.

Thus, the further SWV experiments in this work were performed using a frequency of $60 \mathrm{~Hz}$, a scan increment of $10 \mathrm{mV}$, a pulse height respectively of $60 \mathrm{mV}$ and a window potential ranging from -1.3 to $0 \mathrm{~V}$. The phosphate buffer solution $\mathrm{pH}$ value is 5.2.

With the aforementioned optimum conditions, we established two calibration curves, in a different range of concentrations of Glyphonet SL 360, concentration range in a phosphate buffer solution at $\mathrm{pH} 5.2$ using carbon fiber microelectrode as reported.

When recorded in the concentration range from 100 to $1000 \mu \mathrm{g} \mathrm{L}^{-1}$ using the Glyphonet formulation SL 360, one can observe in Figure 4, the increase of the current intensity with the pesticide concentration. The linear regression is expressed in the following equation $I p / \mu \mathrm{A}=0.0115 \mathrm{C}+7.4353\left(\mathrm{R}^{2}=\right.$ 0.98 ) for the concentration up to $100 \mu \mathrm{g} \mathrm{L}^{-1}$ with a standard deviation (SD) equal to 0.1 .

Moreover, examination of the glyphosate reduction potential in Glyphonet SL 360 shows that its reduction potential shifts toward a more cathodic value by comparison with the value obtained when standard is used. Indeed, it evolves from - 830 $\mathrm{mV}$ to $-950 \mathrm{mV}$ versus $\mathrm{Ag} / \mathrm{AgCl}(\mathrm{KCl} 0.1$ $\mathrm{M})$. This potential shift can be explained by the presence of different adjuvants in the formulation making glyphosate more difficult to reduce (Jones et al., 2007)

At lower concentrations, a straight line plotting of the current intensity versus glyphosate concentration in the range 50 - 150 $\mu \mathrm{g} \mathrm{L^{-1 }}$ is obtained. The linearity of this representation is illustrated by the equation $I p$ $=0.0006 \mathrm{c}+0.0154\left(\mathrm{R}^{2}=0.9975\right)$ with a $\mathrm{SD}$ of 0.005 .

The limit of detection and the limit of quantification were estimated by using the following formula $\mathrm{LOD}=3 * \mathrm{SD} / \mathrm{m}$, and the $\mathrm{LOQ}=10^{*} \mathrm{SD} / \mathrm{m}$, where $\mathrm{SD}$ is the standard deviation and $\mathrm{m}$ the average of the slope of regression line according to Burgess (2000). The obtained value is equal to ca. $25 \mu \mathrm{g} \mathrm{L} \mathrm{L}^{-1}$ and $83 \mu \mathrm{g} \mathrm{L}^{-1}$ for LOD and LOQ, respectively. Compared with our work, Burgess et al (2000) obtained a LOD of $12 \mu \mathrm{g}$ $\mathrm{L}^{-1}$. 
In previous work, Friestad and Brønstad (1985) reported an improvement to the first glyphosate determination method using polarography with detection and quantification limits of 500 and $1000 \mu \mathrm{g} \mathrm{L}^{-1}$, respectively. In an earlier work using the SWV (Teofilo et al., 2004; Sato et al., 2001) a linear response range of 0.050 to $100.0 \mathrm{mg} \mathrm{L}$ ${ }^{1}$, detection and quantification limits of 25 and $80 \mu \mathrm{g} \mathrm{L}^{-1}$, respectively, were obtained. Sato (2001) utilized anion-exchange chromatography with integrated pulsed amperometric detection (IPAD) and under optimized conditions; the detection limit was $50 \mu \mathrm{g} \mathrm{L}^{-1}$ and the linearity range from $0.1 \mathrm{up}$ to $50 \mathrm{mg} \mathrm{L}^{-1}$. Thus, our work presents a great improvement in the determination of glyphosate by electrochemical techniques, principally by SWV using naked carbon fiber microelectrode without sample clean-up and derivatization. The detection limit of $25 \mu \mathrm{g} \mathrm{L}^{-1}$ is better than the value obtained by chromatographic methods and comparable with the existing electrochemical techniques in the literature.

\section{Analytical application for glyphosate determination in soils}

To validate this method, fortification experiments were performed using uncontaminated soil samples from the study area. A series of three (03) soil samples were spiked with Glyphonet SL 360 at concentrations level of 50,100 and $200 \mu \mathrm{g} \mathrm{L}$

${ }^{1}$. One sample without spiking was used as a blank. The glyphosate residues were analyzed in triplicate using the above optimized SWV conditions in $\mathrm{pH} 5.2$ phosphate buffer solution. In order to compare the obtained results, the same samples were studied with validated reverse high performance liquid chromatography with a high sensitive diode array detector. The obtained results are reported in Table 1.

Table 1 shows glyphosate recovery from fortified soil samples. The results for these three samples indicate a reasonable precision due to complexity. The data are in agreement with the literature ones which indicate that a validated method must have a recovery comprised between $70 \%$ and $120 \%$ (DG-SANCO, 2007).

In Table 2, we summarize the data obtained from the determination of the glyphosate residues in soils collected from the sites where Glyphonet SL 360 was applied. The samplings were realized on the first and the fifteenth day following the Glyphonet application.

As shown on Table 2, the amounts of glyphosate residues were determined according to the procedure described above in different soils after one and fifteen days following the treatment. One can see that the amounts of glyphosate in soils are important the day after application and this result is in agreement with reported work (Teofilo et al., 2008). The same analysis carried out 15 days post-treatment reveals the residual amounts of glyphosate residue are below LOD. These observations can be explained by a possible degradation of glyphosate, which could be influenced by the presence of some ions such as $\mathrm{Fe}^{3+}$ and $\mathrm{Al}^{3+}$ (Grunewald et al., 1998) on one hand and by the rainy season on the other hand. In order to confirm this hypothesis, we made a characterization of the different studied soils and the obtained results show that they are low in organic matter and phosphorus but rich in metallic cations like exchangeable aluminum and free iron which could accelerate the decomposition of glyphosate. Moreover, the analysis of groundwater shows two weeks after the application that the amount of glyphosate is lower than the detection limit. All these obtained data demonstrated the possibility to use of CFME for electrochemical analysis of glyphosate in soils as a low cost and sensitive method for glyphosate residue determination in soils and water. 


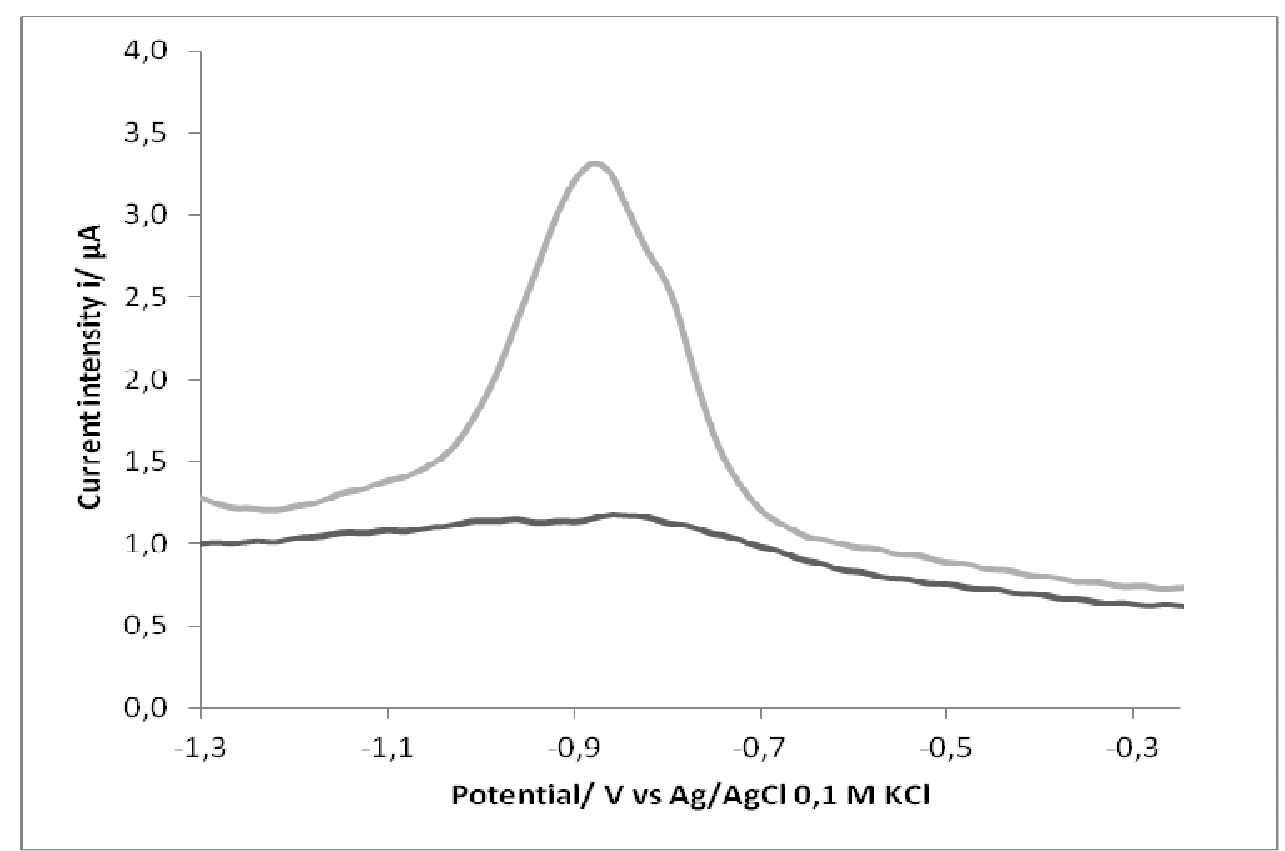

Reference electrode: $\mathrm{Ag} / \mathrm{AgCl} 0.1 \mathrm{M} \mathrm{KCl}$. frequency F = $20 \mathrm{~Hz}$; pulse height: $5 \mathrm{mV}$; scan increment: $20 \mathrm{mV}$.

Figure 1: Square wave voltammograms of phosphate buffer solution $\mathrm{pH} 5$ (black) and $40 \mu \mathrm{g} \mathrm{L}^{-1}$ of glyphosate (grey) using CFME $(\square \Phi=12 \mu \mathrm{m})$.

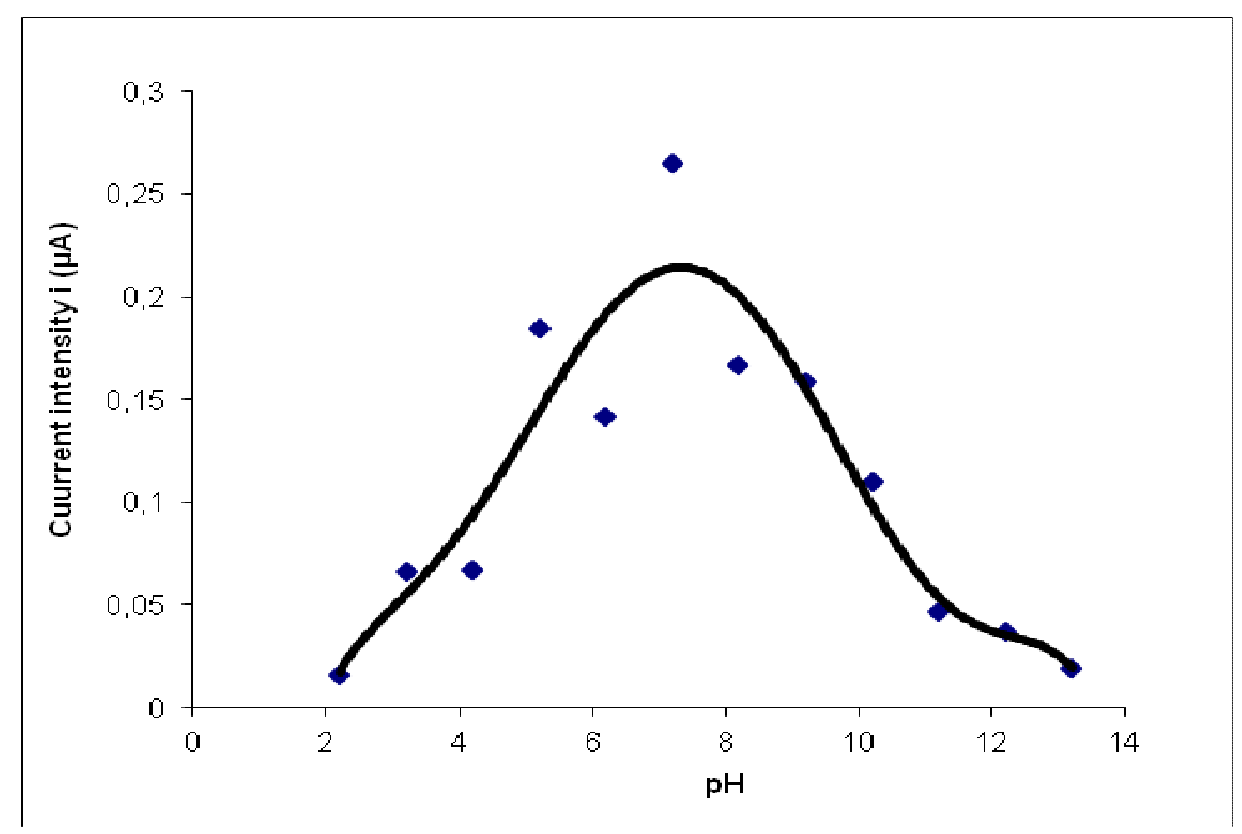

Figure 2: $\mathrm{pH}$ effect on the current intensity of the glyphosate reduction using CFME ( $\Phi=12 \mu \mathrm{m})$. Reference electrode: $\mathrm{Ag} / \mathrm{AgCl} 0.1 \mathrm{M} \mathrm{KCl}$, frequency $10 \mathrm{~Hz}$, scan increment: $5 \mathrm{mV}$ and pulse height: $20 \mathrm{mV}$. 


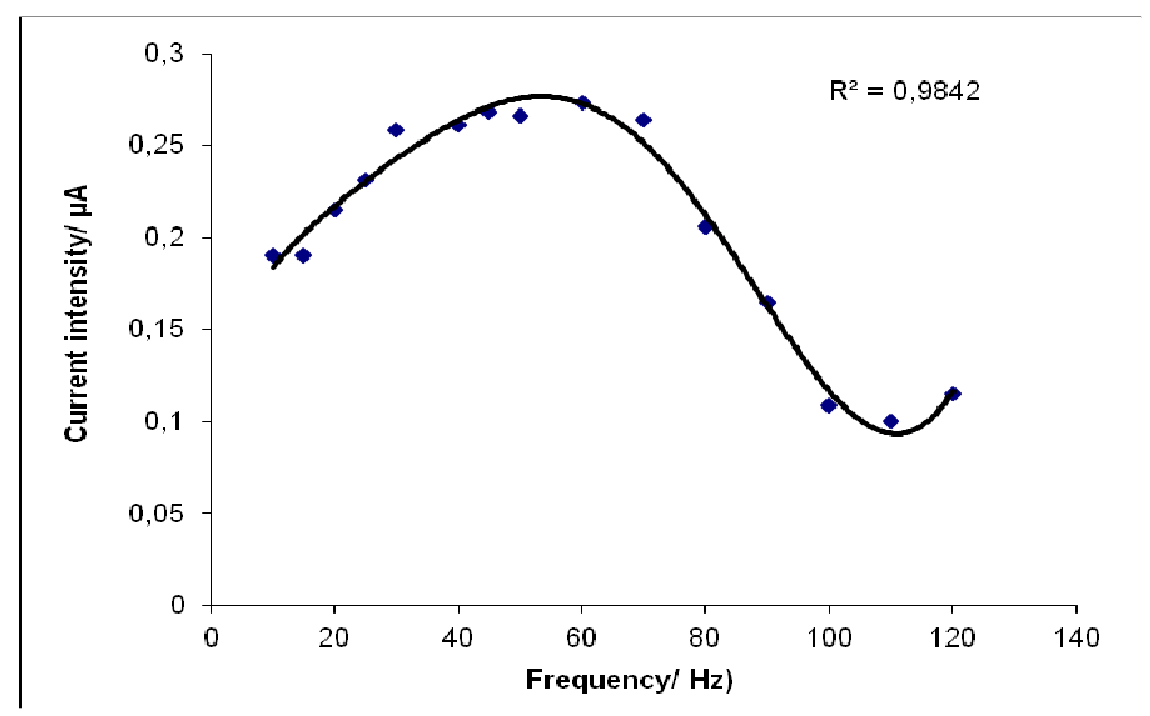

Figure 3: Evolution of the current intensity of the reduction of glyphosate with the frequency in $\mathrm{pH}$. 5.2 phosphate buffer solution using carbon fiber microelectrode working electrode and an $\mathrm{Ag} / \mathrm{AgCl} / \mathrm{KCl} 0.1 \mathrm{M}$ as reference electrode.

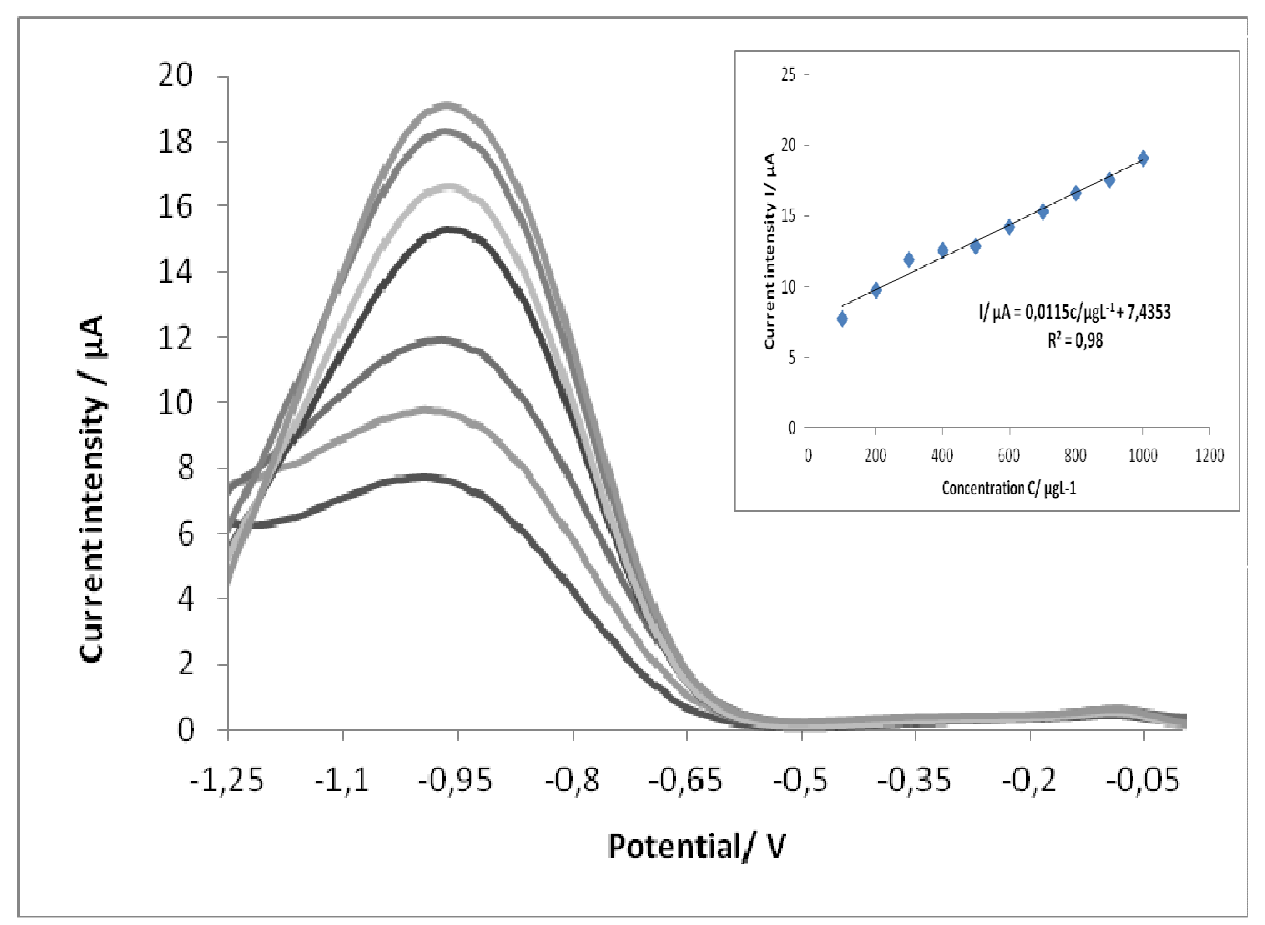

Figure 4: Analytical curves for glyphosate herbicide in Glyphonet SL 360 formulation determination in the concentration range of 100 to $1000 \mu \mathrm{g} \mathrm{L}^{-1}$ in $\mathrm{pH} 5.2$ phosphate buffer solution using carbon fiber microelectrode. Reference electrode: $\mathrm{Ag} / \mathrm{AgCl} 0.1 \mathrm{M} \mathrm{KCl}$. Frequency: $60 \mathrm{~Hz}$. Scan increment: 10 $\mathrm{mV}$. Pulse height: $60 \mathrm{mV}$. 
Table 1: Glyphosate recovery from fortified soil samples.

\begin{tabular}{lccc}
\hline Sample number & HPLC-DAD & SWV & \\
\cline { 2 - 4 } & Glyphosate mean recovery $(\%)$ & SWV SD\% \\
\hline 1 & 90.3 & 88.5 & 11.5 \\
2 & 93.6 & 95.8 & 4.2 \\
3 & 99.3 & 102.3 & 2.3 \\
\hline
\end{tabular}

Table 2: Glyphosate's residues determination in soil samples.

\begin{tabular}{|c|c|c|}
\hline Field \# & $\begin{array}{c}\text { Glyphosate quantification } \\
\mu \mathrm{g} \mathrm{kg} \text { of soil } \\
1 \text { day after }\end{array}$ & $\begin{array}{c}\text { Glyphosate quantification } \\
\mu \mathrm{g} \mathrm{kg}^{-1} \text { of soil } \\
15 \text { days after }\end{array}$ \\
\hline 1 & $184.2 \pm 10.3$ & $<$ LOD \\
\hline 2 & $183.3 \pm 9.6$ & $<\mathrm{LOD}$ \\
\hline 3 & $179.7 \pm 11.5$ & $<\mathrm{LOD}$ \\
\hline 4 & $152.5 \pm 12.1$ & $<\mathrm{LOD}$ \\
\hline 5 & $89.3 \pm 10.1$ & $<\mathrm{LOD}$ \\
\hline 6 & $106.6 \pm 11.3$ & $<$ LOD \\
\hline
\end{tabular}

\section{Conclusion}

The present study reports, for the first time, the elaboration of a remarkably sensitive carbon fiber microelectrode (CFME) for glyphosate residues determination in soils treated by Glyphonet SL 360 formulation using square wave voltammetry. The best performances were obtained using SWV techniques with the following parameters: frequency $60 \mathrm{~Hz}$, pulse height $60 \mathrm{mV}$ and a scan increment $10 \mathrm{mV}$; thus a LOD of $25 \mu \mathrm{g}$ $\mathrm{L}^{-1}$ and a LOQ of $83 \mu \mathrm{g} \mathrm{L}^{-1}$ are reached for soils spiked with glyphosate. These sensitive tools permit the determination of the residues of glyphosate in soils following its treatment by Glyphonet SL 360 formulation with a precision close to previous study but more efficient, sensitive and mainly low cost and rapid. In perspective, we will pursue this study by increasing the sensitivity of CFME using a surface modification as we reported recently (Tapsoba et al., 2009).

\section{ACKNOWLEDGMENTS}

This work was supported by the Group DTE DATONG Entreprises. Authors would to thank them for the financial support and for kindles providing glyphosate standard and Glyphonet SL 360 formulation. One of the authors (Issa Tapsoba) would like to thank COMSTECH/IFS (International Foundation for Science) for his grant NO. W/4394-1

\section{REFERENCES}

Aquino Neto S, Andrade AR. 2009. Electrochemical degradation of glyphosate formulations at DSA ${ }^{\circledR}$ anodes in chloride medium: an AOX formation study. J. App. Electrochem., 39: 18631870.

Borggaard OK, Gimsing AL. 2008. Fate of glyphosate in soil and the possibility of leaching to ground and surface waters: a review. Pest Manag. Science, 64: 441456.

Bott S, Tesfamariam T, Kania A, Eman B, Aslan N, Römheld V, Neumann G. 20011. Phytotoxicity of glyphosate soil residues re-mobilised by phosphate fertilization. Plant and Soil, 342: 249263. 
Brønstad JO, Friestad HO. 1976. Method for determination of glyphosate residues in natural waters based on polarography of the $N$-nitroso derivative. Analyst, 101: 820-824.

Burgess C. 2000. Valid Analytical Methods \& Procedures. RS.C, Tyne and Wear: New York.

Daňhel A, Moreira JC, Jacob S, Barek J. 2011. Influence of the soil organic matter content on voltammetric determination of derivatised glyphosate in herbicide contaminated soils. Collection of Czechoslovak Chemical Communications, 76: 1263-1275.

De Amarante OP, Dos Santos T, Brito NM, Ribeiro ML. 2002. Glyphosate: properties, toxicity, use and legislation. Quim. Nova, 25: 589-593.

DG-SANCO. 2007. Method validation and quality control procedures for pesticide residues in food and feed. Document No. SANCO/2007/3131.

Franz JE, Mao MK, Sikorski JA. 1997. Glyphosate: A Unique Global Herbicide. American Chemical Society (ACS): Washington, D.C.

Friestad HO, Brønstad JO. 1985. Improved polarographic method for determination of glyphosate herbicide in crops, soil, and water. J. Assoc. Off. Anal. Chem., 68: 7679.

Garcia AF, Rollemberg MD. 2007. Voltammetric determination of glyphosate in natural water with a copper electrode. Quim. Nova., 30: 1592-1596.

Grunewald K, Schmidt W, Unger C. 2001. Behavior of glyphosate and aminomethylphosphonic acid (AMPA) in soils and water of reservoir Radeburg II catchment (Saxony/Germany). J. Plant. Nutr. Soil Science, 164: 65-70.

Haney RL, Senseman SA, Hons FM, Zuberer DA. 2000. Effect of Glyphosate on Soil Microbial Activity and Biomass. Weed Science, 48: 89-93.

Ibañez M, Pozo OJ, Sancho JV, López FJ, Hernández F. 2006. Re-evaluation of glyphosate determination in water by liquid chromatography coupled to electrospray tandem mass spectrometry. J. Chromato. A., 1134: 51-55.

Izutsu K. 2002. Electrochemistry in Nonaqueous Solutions. Wiley-VCH Verlag: Darmstadt.

Jones EJ, Hanks JE, Wills GD, Mark RE. 2007. Effect of two polysaccharide adjuvants on glyphosate spray droplet size and efficacy. Weed Technol., 21: 171-174.

Moraes FC, Mascaro LH, Machado SAS, Brett CMA. 2010. Direct electrochemical determination of glyphosate at copper phtalocyanine/Multiwalled carbon nanotube film electrodes. Electroanalysis, 22: 1586-1591.

Morrison ML, Meslow EC. 1984. Effects of the Herbicide Glyphosate on Bird Community Structure, Western Oregon. For. Sci., 30: 95-106.

Nicholls PH, Evans AA. 1991. Sorption of lonisable organic compounds by field soils. Part 2: Cations, bases and zwitterions. Pest. Sci., 33: 331-345.

Official Journal of the European Communities L221. 2002. Commission Decision (2002/657/EC) of 12 August 2002. Brussels, Belgium, 8-36.

Pintado S, Montoya MR, Rodriguez-Amaro R, Mayen M, Mellado JMR. 2012 Electrochemical Determination of Glyphosate in Waters Using Electrogenerated Copper Ions. Int. J. Electrochem. Sci., 7: 2523-2530.

Pontié M, Sikpo L, Thouand G, Lahan R, Tapsoba I, Mallet R, Feng T. 2010. Direct electroanalysis of p-nitrophenol (PNP) in estuarine and surface waters by a high sensitive type $\mathrm{C} / \mathrm{p}$-NiTSPc coating carbon fiber microelectrode (CFME). Electroanalysis, 23: 433-441.

Rueppel M, Brightwell BB, Schaefer J, Marvel JT. 1977. Metabolism and degradation of glyphosate in soil and water. J. Agric. Food Chem., 25: 517528.

Sato K, Jin JY, Takeuchi T, Miwa T, Suenami K, Takekoshi Y, Kanno S. 2001. 
Integrated pulsed amperometric detection of glufosinate, bialaphos and glyphosate at gold electrodes in anion-exchange chromatography. J. Chromatogr. A., 919: 313-320.

Sbaï M, Essis-Tome H, Gombert U, Breton T, Pontié M. 2007. Electrochemical stripping analysis of methyl-parathion (MPT) using carbon fiber microelectrodes. Sens. Actuators B., 124: 368-375.

Shifu C, Yunzhang L. 2007. Study on the photocatalytic degradation of glyphosate by $\mathrm{TiO}_{2}$ photocatalyst. Chemosphere, 67: 1010-1017.

Smyth WF, Watkiss P, Burmicz JS, Hanley HO. 1975. A polarographic and spectral study of some $\mathrm{C}$ - and $\mathrm{N}$ - nitroso compounds. Anal. Chim. Acta, 78: 81-92.

Tapsoba I, Bourhis S, Feng T, Pontie M. 2009. Sensitive and Selective Electrochemical Analysis of Methylparathion (MPT) and 4-Nitrophenol (PNP) by a New Type p-NiTSPc/p-PPD
Coated Carbon Fiber Microelectrode (CFME). Electroanalysis, 21: 1167-1176.

Tapsoba I, Kaboré B. 2012. Electrochemical monitoring of parathion methyl degradation based on carbon fiber microelectrodes. Int. J. Biol. Chem. Sci., 6(2): 864-870.

Teófilo FR, Efraim Reis L, Reis C, Da Silva AG, Paiva FJ, Kubota TL. 2008. Glyphosate Determination in Soil, Water and Vegetables Using DPV Optimized by Response Surface Methodology. Port Electrochim. Acta, 26: 325-337.

Teófilo RF, Reis EL, Reis C, Da Silva GA, Kubota LT. 2004. Experimental design employed to square wave voltammetry response optimization for the glyphosate determination. J. Braz. Chem. Soc., 15: 865-871.

US EPA. 2006. Technical Factsheet on: Glyphosate. 